\title{
シュメール語の嘆願の文学書簡と その意義について
}

\section{The Sumerian Literary Letter of} Petition and Its Significance

\section{高 井 啓 介 \\ TAKAI Keisuke}

\begin{abstract}
The Old Babylonian Sumerian letters have been divided into three types, archival letter-orders, literary letters, and a particular group of literary letters referred to as "Gottesbriefe" or "letter-prayers." As these terms imply, this third group includes letters addressed to various
\end{abstract} deities, that is, prayers in letter-form.

The "Gottesbriefe" usually have a lengthy opening salutation, continue with a brief self-introduction of the letter-writer, and proceed to the body of the letter, which includes a complaint describing either the causes or the consequences of the letter-writer's suffering, together with a petition for protection or relief from the suffering. It should be strongly pointed out, however, that this formal character of "Gottesbriefe" is also shared by letters addressed to kings and others.

The present writer particularly pays attention to the relationship between the opening salutation and the contents of the body of the letter. He proves that, both in the letters addressed to gods and those to kings, an elongated salutation apparently goes along with the inclusion of a "petition" in the body of the letter. If such relationship is true, there is no good reason to exclude the letters addressed to the kings and others from the group. However if the letters addressed to the kings and others are included in the same group, as those addressed to gods, that is the "letter-prayer" category, the term "letter prayers" is no longer an appropriate label. The present writer proposes that, if a label for this group is necessary, "letter of petition" should be adequate.

* イェール大学大学院中近東言語文明学部博士課程

Ph. D. Student, Department of Near Eastern Languages and Civilizations, Yale University, Graduate School of Arts and Sciences 
The present writer also describes the probable course of the gradual transformation that the Old Babylonian Sumerian archival and literary letters experienced.

\section{I.はじめに}

ウル第三王朝期以降，なかでも古バビロニア期にシュメール語で書かれた書 簡の中に, Gottesbriefe あるいは letter-prayers などという名称を持って呼ば れている一群がある。ファルケンシュタインが最初に注目して以来，そのテキ スト群は Gottesbriefe（神（へ）の手紙）と，まず呼ばれてきた。それは文学類 型とまでは見なされていないが少なくとも書簡を限定的にグループ化可能にす る指標であると考えられており, ベック B. Böckによって形式と内容の分析が 詳細に行われている。Letter-prayers（手紙形式の祈䘠）は，ハローW. Hallo が新たに名づけた呼称であるが, 対象となる書簡は Gottesbriefe とほぼ同じ範 囲にある。「神 (へ) の手紙」は文字通り書簡が神に宛てられたことから付与さ れた名称であり，シュメール語およびアッカド語両言語において見られるが， 古バビロニア期の場合その種の書簡には神に対する嘆願が記されている。手紙 形式の祈䘠」という名称はさらに，そういった嘆願の内容を持つ書簡を祈䘠の テキストとして理解する可能性があることを示すものである。

この両方の呼称は, 古バビロニア期の嘆願の内容を持つ書簡の一群を他の書 簡から限定的に選り分け，その性格を理解することに十分に寄与してきた。し かしその際に神に宛てた嘆願の書簡のみが最終的に選別されたゆえ，古バビロ ニア期のシュメール語書簡についての全体的理解から抜け落ちてしまう部分が 出ている現実がある。その抜け落ちた部分の代表的なものが神以外に宛てた嘆 願の書簡である。それらは形式的に神へ宛てた嘆願の書簡となんら相違すると ころがないにもかかわらず，上述のベックの考察の対象から排除されている。 嘆願の書簡を祈祷のテキストとして理解する方向性も，やはり神に向けられる ものであるという祈䘠の本質的性格ゆえに，それによって，神以外に宛てた書 簡を議論から排除するという流れを変えるには至っていない。この指摘は，一 見細かすぎるように思われるかも知れないが，実のところ古バビロニア時代の 嘆願の書簡に関する研究の出発点として正確な議論の対象を限定するために非 常に重要な論点である。 
そのために，本稿で筆者は，まず嘆願の書簡には，独特の形式的特徵が伴う こと, そしてその特徴が他の書簡との明確な区別のための指標を提供すること を指摘する。そしてその形式的独自性はこれまで「神（へ）の手紙」「手紙形式 の祈祷」といった言葉で選別されていた書簡よりもさらに広い範囲の嘆願の内 容を包含することを指摘し，文学ジャンルとしての嘆願の書簡の範囲を決定す る。さらに，その結果選別された嗼願の書簡が神以外の対象に向けられたもの も含むとするならば,「祈䘠」という性格づけを維持するのがそこでふさわしい かについても議論する。最後に, 嘆願の内容を持つ書簡に至るまでのシュメー ル語書簡の段階的変化についても見直すことになろう。

\section{II. 古バビロニア期シュメール語書簡の類型}

ウル第三王朝期に書簡の大部分を占めたのは「手紙命令文書 letter order」で あった。それは簡略な公的命令や注意を行政官僚機構内で伝達したものである。 個々の書簡は送付先の文書庫に残っていたものであり，手紙命令文書はそれぞ れのテキストがオリジナルであると考えてよい。ウル第三王朝期には, 手紙命 令文書のほかにも, 王と彼のチャンセラー, 総督などの間で交換された王室書 簡，あるいは私人間でやりとりされた書簡が，その内容がフィクショナルであ るものまでをも含めて存在した。それだけではなく, 神や王に向けて嘆願が書 かれた書簡も存在しており，この書簡も元来はアーカイヴァルな性格のもので あったと考えてよいであろうが，現在残っているこの書簡のコピーはすべて， 古バビロニア期に入ってからニップル，ウルなどをはじめとする各地のエドゥ ブバ (書記学校) において，学生の教育目的のために選択・書写されて残った ものである。それはあくまでも後代に恣意的に創出された後代のコピーである ゆえ「文学書簡 literary letters」とも呼ばれる。古バビロニア期に入ってから 新たに生み出されたイシン・ラルサ朝の王室書簡も最終的には同じく文学書簡 への道筋をたどった。手紙命令文書と文学書簡，さらに嘆願の内容を持つ文学 書簡は，次節でみるように，伝達する事柄だけでなく，書簡冒頭部に位置する いわゆる導入の定式においてもそれぞれに相違点がみられる。 


\section{III. 古バビロニア期シュメール語書簡の導入の定式}

\section{1．手紙命令文書}

次に示すイシンのイシュメ・ダガン（1953-1935 B.C.）の時代の書簡（NBC 8863）は，古バビロニア期にはもはや数少ない手紙命令文書である。

1 šà-tam-e-ne

2 ù-ne-a-du 11

31 sag géme

4 èr-ra-ba-ni

$5 \quad$ nibru ${ }^{k i}-$ ta $^{\top} \bar{e}^{-}-\mathrm{a}$

6 šu hé-bar-re

7 iti šu-numun-a

$8 \mathrm{mu}$ diš-me- ${ }^{\mathrm{d}}$ da-gan [lugal-e] en ${ }^{\mathrm{d}}$ nanna $[\mathrm{ur}] \mathrm{i}_{5}{ }^{\mathrm{ki}}[\mathrm{i}] \mathrm{n}$-pàd

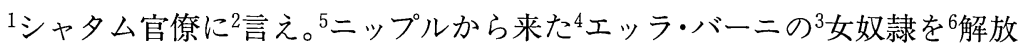
するよjに。7シュヌムナの月。8 $[$ 王である]イシュメ・ダガンがナンナ神に 仕える女性祭司をウルにおいて任命した年。

手紙命令文書の場合, 多くは, 導入の定式（この場合 1-2 行目）は, $\mathrm{PN}_{1}$ (-ra) ù-na-a-du ${ }_{11}\left(\mathrm{PN}_{1}\right.$ に言え!) という形で始まり，まず命令・注意が授けられる 人物が明示された後, 続く部分 (3-6 行目) で命令内容が示される。このタイプ の書簡は個々の用件の確実な伝達が至上命題であったゆえに，導入の定式，伝 達内容ともに装飾性はなくきわめて簡潔である。

\section{2. 文学書簡}

次に文学書簡の導入の定式に関して，イシンのイッディン・ダガンの時代 (1974-1954 B.C.) の王室書簡（ETCSL 3.2.02）を例にとって見てみよう。

1 lugal-g̃á ù-na-du 11

2 mdEN.ZU-illat ra-bi-sí-kà-tum-ma

3 arad-zu na-ab-bé-a

4-11 伝達内容

1わが王(イッディン・ダガン)に対して言え!3あなたのしもべである゙シン・ イッラト, ラビ・シッカトゥム職, がこう言っていると。 ${ }^{4-11}$ (以下,イッ 
ディン・ダガンに対する報告)。

文学書簡は，導入の定式に関しては手紙命令文書の基本的な枠組みを踏襲し， 一般的には以下のような形式となる。

a $\quad \mathrm{PN}_{1}$ and/or TITLE-ra ù-na-a-du ${ }_{11}\left(\mathrm{PN}_{1}\right.$ に対して言え!)

b $\quad \mathrm{PN}_{2}$ na-ab-bé-a（このように $\mathrm{PN}_{2}$ が言っていると）

c＼cjkstart王への指示の要請および王からの指示（王室書簡の場合） 内容は多様 (非王室書簡の場合)

このなかで手紙命令文書にはなかった特徴は，指示・命令を伝達する部分 $\mathrm{c}$ の 長大化であるが，それはウルおよびイシンの王室書簡において極めて典型的で ある。たとえば手紙命令文書が伝達した指示・命令は最大でも10行程度と簡潔 であったが，王室書簡においては，緊急の政治問題に関して，将官からの指示 の要請, あるいは様々な請願, および返答としての王からの指示はきわめて詳 細に記録され，その長さが数十行にまでわたるものも存在する。次の三項目の 表現を文学書簡の多くが共有している。第一の表現 tukumbi lugal-g̃á/g̃u $u_{10}$ anna-kam（もし，わが王が同意するなら）は，現状の報告が終わり，請願に移行 する際にまず最初の文として置かれる。lugal-g̃u I $_{10}$ (me) he-en-zu（わが王 (主) が（このことを）知ってくださるように）との表現は, 王に宛てて書かれた書 簡の末尾において使われる表現であり，請願について王が知り実行するように との期待感をにじませる。最後に a-ma-ru-kam（そのことは危急を要する）も 同様に書簡の最末尾に置かれるが，こちらの表現は，王が彼のチャンセラーに 宛てた返信において好んで使われており，王の命令・指示の危急性が強調され ている。

\section{3. 嘆願の文学書簡}

次に伝達する部分が嘆願からなる文学書簡の導入の定式の特徴を見てみよう。 ニンティヌッガ神に対してイナンナカが書いた書簡は以下のようにはじまる。

1 dnin-tin-ug ${ }_{5}$-ga agrig zi é-kur-ra

2 a-zu kalam-ma-ra ù-na-a-du ${ }_{11}$

3 nin $t_{6} \mathrm{du}_{11}$-ga-ni ũg̃ šár ti-le 
$4 \quad \mathrm{mu}_{7}-\mathrm{mu}_{7}$-a-ni ùğ ša $\mathrm{a}_{6}$-ga

5 nin šà-ne-ša 4 lú ti-ti šùd-dè ki-áğ-ra

6 šà-gur-ru šà-lá-sù a-ra-zu g̃iš-tuku-ùr

7 ù-ne-dè-dah

8 ti-la ug $_{5}$-ga-bi èn-tar-bi za-e-me-en

9 lú $\mathrm{ku}_{5}$ lú $\mathrm{ku}_{5}$-bi duㄱ $-\mathrm{du}_{7}$ gal-bi-me-en

10 mdinanna-ka dumu-munus den-líl-lá-mah

11 géme-zu na-ab-bé-a

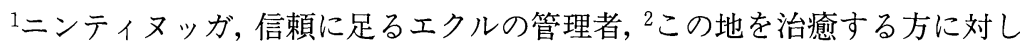
て言え! ${ }^{3}$ その呪文が多くの民を生かす女性， ${ }^{4}$ そのまじないが民を快方に 向かわせ (る女性) ${ }^{5}$ 人々を生かすことと祈りとを愛する心優しい女性, 6 憐 れみ深く温情に富み, 祈りに耳を傾ける方に対して，73たたび言え！ ${ }^{8}$ ふな たは死者と生者の世話をする方, ${ }^{9}$ 身体の不自由なすべての者の治癒者。10 个 ナンナカ, エンリルラマフの娘, ${ }^{11}$ なたのしもべがこのように言っている と。

この種類の導入の定式 (a-b) は一般的な図式としては次のようになる。

$\mathrm{a}_{1} \mathrm{DN} / \mathrm{PN}_{1}$ and/or TITLE-ra +賛辞 ù-na-a-du ${ }_{11}\left(\mathrm{DN} / \mathrm{PN}_{1}\right.$ に対し て言え!)

$\mathrm{a}_{2}$ 賛辞 ù-na-dè-dah （ふたたび言え!)

$\left(\mathrm{a}_{3}\right) \quad$ (賛辞)（ù-ne-dè-peš ${ }_{5}$ ）（三度目に言え!）

b $\mathrm{PN}_{2}$ arad/géme-zu na-ab-bé-a（このようにしもべである $\mathrm{PN}_{2}$ が言 っていると)

\section{C 嘆願}

要請・請願の文学書簡が持つ導入の定式の基本的な枠組みを基本としつつも, 嘆願の内容を備える文学書簡では，a においては受取人である神に対する賛辞 と祝福の文言 $\left(a_{1}\right)$ が付け加わっている。さらに, 新たな賛辞 $\mathrm{a}_{2}$ が付け加えら れて，(ときには三たび賛辞 $\mathrm{a}_{3}$ が加わることもある）, 最終的には冒頭部が二重, 三重に拡大されている。拡大されたこの部分の賛辞は神賛歌の定型表現をおそ 
らくは借用していると思われる。導入の定式の拡大が確認される書簡において， 嘆願が述べられないものは存在しない。また，嘆願が述べられる書簡において は，上述の導入の定式がほぼ全般的に認められるのであり，その例外もわずか 一例を数えるのみである。このような状況からして, 導入の定式の拡大と嘆願 の内容との間に必然的なそして排他的な関係があることは明白である。

\section{IV.「神（へ）の手紙」と嘆願の文学書簡}

このように導入の定式が賛辞によって二重三重へと拡大される書簡において， 嘆願が神ではなく王あるいはそれ以外の人物に向けられる場合も少なくない。

「神（へ）の手紙」というグループ化の名称が定着したのは, 古バビロニア期 および後代の新アッシリア時代のアッカド語書簡のなかに神への書簡が発見さ れており, それらの書簡とあわせて, 神へ宛てて書簡を記すということの特殊 性が注目されたことが大きく寄与している。古バビロニア期の「神（へ）の手 紙」は，一個人が神に宛てて苦境からの救出を嘆願したものであるのに対し， 新アッシリア期のそれは，たとえばサルゴン王が第 8 回目の外征を神に向けて 書簡の形式によせて報告した文書のようなものであっで, 書簡が持つ意味と期 待された役割は両者でかなり隔たっている。両方のテキストを現象面で結びつ けるには便利な呼称であろうが，本論文が取り扱う古バビロニア期の文学書簡 に限ってみれば，嘆願という伝達内容と深い結びつきを持つ導入の定式を備え た書簡が神以外にも宛てて記されているのであるから，「神 (へ)の手紙」とい う呼称に固執する必要はない。このように王ないしはそれ以外の一個人に宛て て書かれた文学書簡をも嘆願という内容の同一性によって議論の範囲に加え， それと嘆願の内容を持たない書簡との連続性と差異, さらにはグループ内部に おいて王に宛てた嘆願の書簡と神に宛てた嘆願の書簡との連続性と差異とを明 らかにしていく道筋のほうが, 古バビロニア期のシュメール語文学書簡の全体 像を描くためには有効であると考える。このような考えに基づいて, 本稿は古 バビロニア期の嘆願の内容を持つ文学書簡の範囲を改めて決定し, (表 1 ) 及び 末尾に (資料) として列挙した。

\section{V. 嘆願部分の文学的構造}

以下では，嘆願の文学書簡に対してなされてきた「祈䘠」という性格付けに 
(17)

表 1 シュメール語の嘆願の文学書簡における諸要素の配置

\begin{tabular}{|c|c|c|c|c|c|c|}
\hline No. & & 恩恵 a & 奉仕 b & 苦境の報告 c & 救出の願い $\mathrm{d}$ & 誓い e \\
\hline 1 & $\begin{array}{l}\text { アバ・インダサ } \\
\rightarrow \text { シュルギ王 }\end{array}$ & & & $14-23$ & 24 & \\
\hline 2 & $\begin{array}{l}\text { イニム・エンリラ } \\
\rightarrow \text { 王 }\end{array}$ & & & $8-9$ & 10 & \\
\hline 3 & $\begin{array}{l}\text { ルガル・ニサグ } \\
\rightarrow \text { エンリル・マッス }\end{array}$ & & & $10-18$ & $19-20$ & \\
\hline 4 & $\begin{array}{l}\text { ルガル・ニサグ } \\
\rightarrow \text { 王 }\end{array}$ & & & $6-23$ & 24 & \\
\hline 5 & $\begin{array}{l}\text { ルガル・ニサグ } \\
\rightarrow \text { 王 }\end{array}$ & & & $\begin{array}{l}\text { 8-22 } \\
\text { 以下判読困難 }\end{array}$ & $?$ & \\
\hline 6 & ウル・シャガ $\rightarrow$ 王 & & & 10 & $11-14$ & \\
\hline 7 & $\begin{array}{l}\text { ニン・シャタパダ } \\
\rightarrow \text { リム・シン王 }\end{array}$ & $20-34$ & & $36-49$ & $35,54-58$ & 53 \\
\hline 8 & $\begin{array}{l}\text { イナンナカ } \\
\rightarrow \text { ニンティヌッガ神 }\end{array}$ & & & $12-18$ & $19-21$ & $22-25$ \\
\hline 9 & $\begin{array}{l}\text { シン・シャムフ } \\
\rightarrow \text { エンキ神 }\end{array}$ & 10 & $11-12$ & $13-40$ & $45-47,54-56$ & $48-53$ \\
\hline 10 & $\begin{array}{l}\text { グデア } \\
\rightarrow \text { 彼の個人神 }\end{array}$ & & & $3-9$ & 10 & \\
\hline 11 & $\begin{array}{l}\text { ナンナ・マンスム } \\
\rightarrow \text { ニンイシンナ神 }\end{array}$ & & & $\begin{array}{l}14-20 \\
\text { 以下欠損 }\end{array}$ & & \\
\hline 12 & $\begin{array}{l}X \rightarrow \text { ナンナ神 } \\
\text { (宛先以外欠損) }\end{array}$ & & & & & \\
\hline 13 & $X \rightarrow$ ウトゥ神 & & & rev. $+1-+5$ & rev. +6 & \\
\hline 14 & $\begin{array}{l}\text { エテル・ピ・多ム } \\
\rightarrow \text { マルトゥ神 }\end{array}$ & 5-7 & $8-12$ & $13-14$ & 15 & 16 \\
\hline 15 & $\begin{array}{l}\text { ク・ナンナ } \\
\rightarrow \text { ニンシュブル神 }\end{array}$ & & & 14, rev.2-4 & rev. 5-10 & rev. 11 \\
\hline 16 & $\begin{array}{l}\text { シン・イッディナム } \\
\rightarrow \text { ウトゥ神 }\end{array}$ & & & $12-31$ & $34-43,45-46$ & 44 \\
\hline 17 & $\begin{array}{l}\text { シン・イッディナム } \\
\rightarrow \text { ニンイシンナ神 }\end{array}$ & 12 & $13-15,19$ & $20-28$ & $41-48$ & \\
\hline
\end{tabular}

ついての考察に移るが，それに先立ってまず嘆願が述べられている部分の構造 を概観しておく必要がある。(表 1 ）の a e は，これらの嘆願の書簡が少なく とも 5 つの要素によって構成されるものと考え, それらの要素の配置を書簡毎 
に示したものである。中心に位置するのは苦境を嘆き救出を願う部分であって， その両要素をともに欠く書簡は存在せず，その両者がすべての書簡の雲囲気を 形成している。

まず苦境（表 1c）であるが，その表現にはいくつかのパターンがある。苦境 の吐露においては, 衰え, 弱さ, 痛みなどの身体的苦痛, それに伴う精神的苦 恼, 家族, 友人から見離されて覚える社会的孤独感, 疎外感が表現されている。 そのような苦境にある個々の人間が, 神や王に自らの苦しみを報告し, 続いて 苦境からの救出を「嘆願」する部分が書簡の核心であったと考えられる (表 $1 \mathrm{~d})$ 。 苦しみをもたらす原因の究明が付随する場合は，その原因が放逐されるように 願う。たとえば神の憤りがその原因であると考えるならばその憤りがなんとか 鎮まるようにと願い，病気を伴ったデーモンに対してはそのデーモンが体内か ら放逐されるようにとの願いを神に訴えるし，職を失ったときは，無実を主張 しつつ, 王に対してその地位の回復を願っている。

神に宛てられた嘆願の書簡においては, 苦境の描写及びそれに続く嘆願を, 前方と後方から挟み込むような形で，しばしば次のような要素が配置されるこ とがある。第一に，自分は神からこれまで様々な形で恩恵を受けてきた人間で あるとの主張がなされ，したがって今回もそのような神の恩恵が自らの上に及 ぶことを期待する（表 1a)。また，自分は神に対してこれまで様々な形の奉仕を 意らなかったとの主張から，そのような忠実さのゆえに救済を受ける資格があ るとの論理が展開される (表 $1 \mathrm{~b})$ 。さらに, 駄目を押すように, 現在の苦境から の解放が達成された時には，必ず神に奉仕し，その神を賛美するとの誓いも最 後に添えられるケースが散見される(表 1e)。

\section{VI. 嘆願の文学書簡と「手紙形式の祈䘠」}

「祈祷」に関していえば，古バビロニア期に至るまでそのために用意された 特別な文学ジャンルの存在があったわけではない。様々な場面において表明さ れる祈りのことばは, 神の前に祈りを携えて行く人間の姿の描写と同様に，神 話や叙事詩, 奉納碑文, 哀歌といった様々なジャンルのテキストのなかに組み 込まれる形で存在していた。また，いわゆる王賛歌といわれる種類のテキスト においては，神に対する賞賛が，王の健康と安寧を求める神への祈りに先立っ て置かれることがある。王の業績あるいは王彼自身の存在のありかたを讃える 
際にも，そのような王をあらしめた神に対する賛辞をまず組み込むことを忘れ ないだけではなく，テキスト自体そのような神々に対する賛歌の形式をとって いることが多い。嘆願の文学書簡冒頭部の導入の定式に置かれる神への賛辞も そのような類のものであると思われるが,この賛辞の部分に「祈䘠」との関係 が見出される。神が祈りを聞き届ける存在であるとの表白は，その神が苦境か らの救出を可能にする存在であるとの確信の表明であるが，そこでは，一般的 な祈りの行為とことばを表す語彙としての šùd (シュド) や arazu (アラズ) が, 「祈りを好み $(\mathrm{a}-\mathrm{c})$, 祈りのことばを傾聴する $(\mathrm{b}-\mathrm{g}) 」$ 神の属性として言及され ている。
a) dnanna dumu-sag̃ den-líl-lá šùd-dè ki-ág̃-ra ナンナ，エンリルの長子，祈りを愛する方へ。(12:1)
b) nin šà-ne-ša 4 lú ti-ti šùd-dè ki-ág̃-ra šà-gur-ru šà-lá-sù a-ra-zu g̃iš-tuku-gu $u_{10}$-úr 憐れみ深い女性，人を生かし，祈りを愛する方へ。 同情的で，情け深く，祈りを聞き届ける方へ。(8:5-6)
c) šùd-dè ki-ág̃ a-ra-zu g̃iš-tuku 祈りを愛し，願いを聞き届ける方。(17：9)
d) dig̃ir arḩuš sù šà-gur-ru a-ra-zu-e g̃iš-tuku 慈悲深く，同情的で，祈りを聞き届ける神。(12:6)

e) dig̃ir zi lú-ti-le-dè ki-ág̃ a-ra-zu g̃iš-tuku 清らかな神，人を生かすことを好み，祈りを聞き届ける方。(16:3)

f) šà-lá-sù lú zi-dè ki-áğ inim!-šùd a-ra-za g̃iš-tuku 情け深く，清らかな人を好み，祈りのことばと願いを聞き届ける方。 $(14: 2)$

g) dnin-šubur dig̃ir šà-lá-sù šùd a-ra-zu g̃iš-tuku ù-ne-dè-dah ニン・シュブル神, 情け染く, 祈りと願いを聞き届ける神へ, ふたた び伝えよ。(15：12)

その一方で, 救出の願いそれ自体は, 肯定 (h-1) および否定の願望 (m-n), あ るいは動詞の命令形 (o-q)によって表現される。

h) du $u_{11}$-ga den-líl-lá-ta mùš-me-zu hé-bí-íb-du 
あなたの御顔がエンリルの指示に従って，わたしに好意を寄せてくだ さいますように。(3：20)

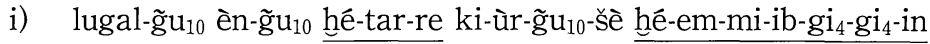
わが王が私の面倒を見てくださるように。私がもといた場所に戻れま すように。(4:24)

j) g̃á-a me-na-àm šà- ďsul-gi lugal-g̃á ki-bi ha-ma-gi $i_{4}$-gi ${ }_{4}$ わが王シュルギの心はいつこの私のもとに帰ってくるのでしょう か? $(1: 24)$

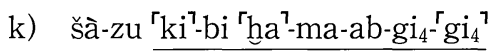
あなたの心がわたしのもとに戻ってきますように。(10：10)

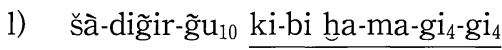
わが神の心が私のもとに帰ってきますように。(9：56)

m) g̃ìri-PAD-rá-g̃u $u_{10}$ šà-uru-kúr-ra-šè nam-ma-an-tùm わたしの骨が水に流されて異国の地へ運ばれていきませんように。

$$
(2: 10)
$$

n) é-ad-da-g̃á lú nam-ba-ab-tùm ki-ùr é-ad-da-g̃á lú nam-mu-da-an-kar-re 私の父の家産を誰も運び去ることがありませんように。 私の父の家産の礎を誰も奪い去ることがありませんように。(6：1213)

o) šul dutu nam-bi-šè uru-zu larsa ${ }^{\text {ki }}$-ma igi zi bar-mu-un-ši-ib 若きウトゥよ，そのことのゆえに，どうかあなたの都市ラルサに真摰 に目を振り向けてください。(16：34)

p) arhuš ${ }^{\Gamma}$ sù larsa ${ }^{k i}{ }^{1}$-ma šu te-ba-ab ラルサにどうか憐れみを向けてください。(16：37)

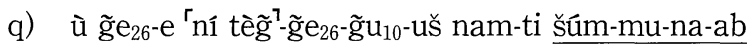
zi sù-ud-g̃ál níğ-ba-e-éš ba-mu-na-ab そしてこの私には，私のあなたへの畏れのゆえに，どうかいのちを与 えてください。 私には，贈り物として，果てない命をどうか割り当ててください。 $(16: 45-46)$ 
上記のような祈りという意味の語彙及び願望を意味する表現の存在が，嘆願の 内容を持つ文学書簡に付随する形式の特徵をなす部分であることは確かである。 ただし祈祷を表現する言葉が含まれているからといって即座にそのテキストが 祈䘠のテキストであるということにはならない。むしろ，V.で示した嘆願の文 学書簡の構造全体こそが祈䘠のテキストにふさわしい性格を与えている。シュ メール・アッカド文学において祈䘠のテキストの典型は, 神への呼びかけでは じまり，その神に対する賛美が献げられた後，嘆願が続き，祈りが聞き届けられ た際の賛美の約束で終わるが，後代におけるその代表的なテキスト群がエルシ

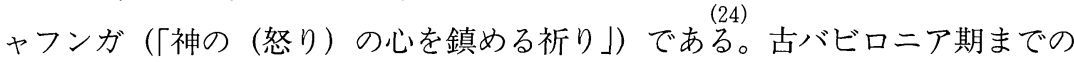
シュメール文学においてはこのような要素をすべて兼ね備えた祈祷のテキスト は多くなく, 末尾に付した (資料) で示した導入の定式および（表 1 ）を併せて みるときに，嘆願の文学書簡になってはじめて以上の要素が出揃ったことがわ かるのである。エルシャフンガはミカロウスキによって指摘されるように, 少な くとも 8 点のコピーが古バビロニア期に既に存在していたようである。そのな かでも, とくに BM 29632 の終わりの二行には, 一部の嘆願の文学書簡の終結部 にもみられるフレーズ（前頁の例 $\mathrm{j}-1$ ) である次のような表現が使われている。

šà-zu šà ama tu-da-gin 7 ki-bi ḩa-ma-gi ${ }_{4}-g i_{4}$ ama tu-da a-a tu-da-gin $\mathrm{ki}$-bé ha-ma-gi $4_{4}-\mathrm{gi}_{4}$ あなたの心が，私を生んだ母の心のように，私のところに戻ってくるよう に。

私を生んだ母，私を生んだ父のように，私のところに戻ってくるように。

おそらく以上のような複数の意味において，「手紙形式の祈神」というハローに よる呼称は，嘆願の書簡の持つ意味に関して正しい方向を指し示している。た だし，この呼称に関しても嘆願の書簡には神以外に宛てて書かれたものを含め ることが適当であると考えるゆえに，すべてを一様に祈䘠であると断定するこ とには躊躇する。むしろ請願の延長として王に自らの置かれた状況を嘆きとい う形で報告し，王からの返答を期待したケースもあったと考えることもあなが ち誤りではないであろう。従って, 形式的な共通性から考えて王に対する書簡 にまで考察の範囲を及ぼす場合は，嘆願の書簡というグループ化までにとどめ ておくのがふさわしいであろう。 
それでは，「祈祷」とも理解されうる神に宛てられた嘆願の文学書簡は，なに ゆえに書簡という文学形式を通して表明されたのであろうか。ハローは，奉納 物の安価な代替手段として，書簡（たった一枚のそれほど大きくない粘土板） 形式が追求されたと考える。たとえばある嘆願の文学書簡のなかに以下のよう な記述がある。

ù-na-a-du $u_{11}$ mu-ra-gub-ba-g̃u $u_{10}$ arhuš tuku-ma-r[a]

私があなたの前に安置するこの手紙に憐れみを向けて下さるように。（9： 55)

もしこのような状況が一般的なものであったならば，公的儀礼に組み込まれな いいわゆる「個人の嘆き」の表明のための手段として，神に向けられた嘆願の 書簡は意義が大きいことになる。

\section{VII. シュメール語嘆願の文学書簡の影響史}

シュメール語の嘆願の文学書簡については, 二つの方面で後代の類似テキス トへの形式上あるいは内容上の影響関係がすでに指摘されている。それは，第 一にアッカド語の嘆願の書簡に対して，そしてマリにおいて発見されている類 の書記の嘆願の書簡に対してである。

アッカド語の嘆願の書簡に関しては, 本稿の筆者はすでにその特徵について 論じたことがあるが, その際先行の議論を整理するとともに，シュメール語の 嘆願の文学書簡との比較可能性についても検討した。アッカド語のそれは, 書 記学校においてコピーされ伝承されていったシュメール語による書簡とは異な り，原則的にはアーカイヴァルな書簡である。シュメール語の嘆願の文学書簡 において冒頭部が拡大されるのに対し，アッカド語の場合おそらくは書き手の 個人神への嘆願の表白であるがゆえか，冒頭部が通常の文書庫所属の書簡と同 じ形態をとる。そういう意味では両者は明確な接点を欠いているようにも見え る。ただし, アッカド語の嘆願の書簡のうち, シン・ナディン・シュミムから ナブ神に向けて書かれたケース (Ni. 13088) では, 通常のアーカイヴァルな アッカド語の嘆願の書簡には見られないシュメール語の嘆願の文学書簡との見

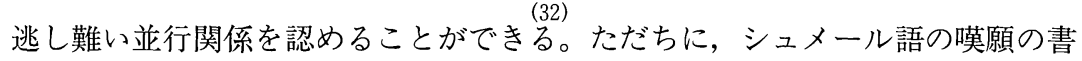
簡からの影響であると結論づけることには躊躇があるものの, 問題となってい るナブ神宛の書簡が古バビロニア時代末期に書かれたこと, さらにはシュメー 
ル語の文学書簡数通に付されたアッカド語のグロスに, ナブ書簡の導入の定式 において使用される表現（Šunnišum， šullissum）などが使われていることもあ ク，通常のアッカド語書簡においてそのような導入の定式を持つものが極めて まれであることから考えても，全くの影響関係を認めないことはかえって不自 然であろう。

シュメール語の嘆願の書簡には, いま述べたように, アッカド語のグロスが 添付される場合がある。このいわゆるバイリンガル・テキストは第一義的にシ ユメール語の習得を目的とする学習が行われた各地の書記学校において作成さ れたものであり，簡単なグロスあるいは行ごとの訳出のいずれであれ，シュメ 一ル語の一つの行に対してアッカド語が配置されるいわゆるインターリニアタ イプをとっている。古バビロニア時代のマリからも二言語が併記されている書 簡 (A. $1258+$ S. $160 \mathrm{SN})$ の存在が知られている。ジムリ・リム王宛のこの書簡 は, 上述の二言語併記書簡とはそのスタイルが異なり, むしろ王碑文と同様に シュメール語を粘土板の左欄にまたアッカド語を右欄に配置する。この書簡は， 嘆願の文学書簡の形式を模した書記が自己の名誉回復をジムリ・リムに対して 行ったものであり，自らの特技をシュメール語と示した再就職用のレジュメと 考えられようう。その意味でバビロニア本土出土の嘆願の書簡が持つような祈祷 の性格は初めからない。むしろ，マリのジムリ・リム書簡は同様の失職した書 記の苦悩を王女に対して吐露したカッタラ出土のイルタニ書簡との関係性が指 摘されよゔ。

\section{VIII. おわりに}

最後に，書簡の文学化の進展の経緯およびその流れのなかでの嘆願の書簡が 持つ意義を考えておきたい。明らかに，文学書簡の形式・内容を踏襲しつつも， 伝達内容が嘆願を含む場合，その両者が呼応しつつ発展・展開したことが理解 されたと思う。書簡という文学形式の融通性がそのような状況を生んだ。書簡 形式をとりながら行政命令文書は官僚機構内における上から下への指令の伝達 という役割を担った。一方で，文学書簡の多くは，公的な報告や個人的な意見 の表明のために使われると同時に，それに対する回答を期待するという点で多 くの場合双方向性を持った。請願の文学書簡では王への現況報告であったもの が，嘆願の文学書簡では王・神への苦しみと嘆きの報告となったし，王が問題 
に気づくことを願うとの要請は，王・神が目を留状況を改善してくれるよう にとの懇願となった。王に対する書簡の場合は返答が期待されたこともありえ ようが，神に対してはそもそも「祈祷」としての一方向性に留まったものと思 われる。

ラルサ期の嘆願の書簡（末尾資料 7，16，17）は，このような展開の流れの最 終局面である。これら三通はまず文面が長大でどれも50行前後を数える。ウト ウへの書簡（16）には，エマル，および新アッシリア時代からのコピーが存在 しており，単一の書簡からの証拠ながらも，どうやら神や王への嘆願の書簡と いう形式が後代にも受け継がれていたことが伺える。既に述べたように書簡形 式による嘆願はアッカド語においても古バビロニア時代においても存在するし， 新アッシリア時代には書簡形式が神に対する王の戦勝報告を内包する形で発展 していくことは前述の通りであるが，そちらの展開は本稿の射程外であるため， また稿を改める。

\section{[資料]}

\section{嘆願の内容を持つ文学書簡の一覧}

以下の書簡はすべて古バビロニア期のコピーである。また，以下において ETCSL とは， シュメール語の文学テキストを網羅しようとするオックスフォード大学のデータベース を指す (http://etcsl.orinst.ox.ac.uk)。ただし, このデータベースは常に更新され続けてい て，テキストによっては現在の情報が最終情報ではないこともある。

1. アバ・インダサ $\rightarrow$ シュルギ王

ETCSL 3.1.21

失職した書記が王に復職を嘆願

$\mathrm{a}_{1} \quad$ lugal-g̃u $\mathrm{u}_{10}$-ra ù-na-du $\mathrm{ul}_{11}$ (1)

$\mathrm{a}_{2}$ 賛辞 (2-4) ù-na-dè-dah (5)

b ma-ba-in-da-sá ... árad-zu na-ab-bé-a (6-8)

c 嗼願 (9-24)

2. イニム・エンリラ $\rightarrow$ 王

ETCSL 3.3.27

囚われの書記が救出を嘆願

$\mathrm{a}_{1}$ lugal 賛辞 (A1-2) ù-na-a-du $\mathrm{Al}_{11}(\mathrm{~A} 2)$

$\mathrm{a}_{2}$ 賛辞 (A3-4) ù-na-dè-dah (A5)

b minim- ${ }^{d}$ en-lîl-lá ... arad-zu na-ab-bé-a (A6-7)

c 嘆願 $(\mathrm{A} 8-\mathrm{B} 1+)$

3. ルガル・ニサグ $\rightarrow$ エンリル・マッス ETCSL 3.3.09

苦境を嘆き乥こからの救出を願う 
$\mathrm{a}_{1}$ den-líl-mas-su 賛辞 ù-na-a-du $\mathrm{u}_{11}$ (1)

$\mathrm{a}_{2}$ 賛辞 (2) ù-na-dè-dah (3)

$\mathrm{a}_{3}$ 賛辞 (4-7) ù-na-dè-peš (7)

b mlugal-nisag̃-e ... na-ab-bé-a (8-9)

c 嘆願 $(10-20)$

4. ルガル・ニサグ $\rightarrow$ 王

ETCSL 3.3.02

敵対者からの迫害を嘆き庇護を願う

$\mathrm{a}_{1}$ lugal 賛辞 (1) ù-na-du $\mathrm{u}_{11}$ (2)

$\mathrm{a}_{2}$ 賛辞 (3-4) ù-na-dè-dah (4)

b mlugal-nisag̃-e ... árad-zu na-ab-bé-a (5)

c 嘆願 (6-24)

5. ルガル・ニサグ $\rightarrow$ 王

ETCSL 3.3.03

罰による苦しみからの救出を嘆願

$\mathrm{a}_{1}$ lugal 賛辞 (1) ù-na-du $\mathrm{du}_{11}$ (2)

$\mathrm{a}_{2}$ 賛辞 (3-5) ù-na-dè-dah (6)

b mlugal-nisag̃-g̃ $e_{26}$... árad-zu na-ab-bé-a (7)

c 嘆願 (8-33)

6. ウル・シャガ $\rightarrow$ 王

(アッカド語のグロスあり)

$\mathrm{a}_{1}$ lugal 賛辞 (1) ù-na-a-du $\mathrm{du}_{11}$ (2)

$\mathrm{a}_{2}$ 賛辞 (3-5) ù-na-dè-dah (5)

$\mathrm{a}_{3}$ 賛辞 $(6-8)$

b ${ }^{\text {md }}$ ur-ša $_{6}$-ga arad-zu na-ab-bé-a (9)

c 嘆願 (10-14)

7. ニンシャタパダ $\rightarrow$ リム・シン王

$\mathrm{a}_{1}$ lugal-g̃u $\mathrm{u}_{10}$-ra ù-na-a-du $\mathrm{u}_{11}$ (1)

$\mathrm{a}_{2}$ 賛辞 ù-na-dè-dah (2-7)

$\mathrm{a}_{3}$ 賛辞 ù-ne-dè-peš (8-15)

b mínin-šà-ta-pa-da ... géme-zu na-ab-bé-a (16-19)

c 嘆願 (20-58)

8. イナンナカ $\rightarrow$ ニンティヌッガ神

ETCSL 3.3.10

病魔からの解放を願う

$\mathrm{a}_{1} \mathrm{~d}_{\text {nin-tin-ug }}$-ga 賛辞 ù-na-a-du $\mathrm{u}_{11}(1-2)$

$\mathrm{a}_{2}$ 賛辞 (3-6) ù-na-dè-dah (7)

$\mathrm{a}_{3}$ 賛辞 $(8-9)$

b mdinanna-ka ... géme-zu na-ab-bé-a (10-11)

c 嘆願 (12-25) 
9. シン・シャムフ $\rightarrow$ エンキ神

失職した書記が地位の回復を願う

$\mathrm{a}_{1}$ den-ki 賛辞 (1) ù-na-a-du ${ }_{11}$ (2)

$\mathrm{a}_{2}$ 賛辞 (3-6) ù-na-dè-dah (7)

b dEN. ZU-ša-mu-úh ... arad-zu na-ab-bé-a (8-9)

c 嘆願 (10-56)

10. グデア $\rightarrow$ 彼の個人神

ETCSL 3.3.20

個人神に苦境からの救出を請う
$\mathrm{a}_{1}$ dig̃ir-g̃á ... ù-na-du $\mathrm{u}_{11}$ (1)
b mgù-dé-a arad-zu na-ab-bé-a (2)
c 嘆願 (3-10)

11. ナンナ・マンスム $\rightarrow$ ニンイシナ神ＥTCSL 3.3.21

不成功に終わった医術に関して
$\mathrm{a}_{1} \quad{ }^{\mathrm{d}}$ nin-ì-si-in-na 賛辞 (1-11) ù-na-a-du $\mathrm{u}_{11}$ (11)
b md nanna-ma-an-sum ... árad-zu na-ab-bé-a (12-13)
c 嘆願 (14-)

12. 差出人不明 $\rightarrow$ ナンナ神

ETCSL 3.3.22

(シュメール語とアッカド語の二言語併記)

嘆願の部分が省略されている

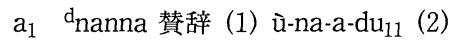

$\mathrm{a}_{2}$ 賛辞 (3-6) ù-na-dè-dah (7)

$\mathrm{a}_{3}$ 賛辞 $(8-16)$

b 省略

c 省略

13. 差出人不明 $\rightarrow$ ウトゥ神

苦境を嘆き罪のゆるしを願う

$\mathrm{a}_{1} \mathrm{~d}_{\mathrm{u}} \mathrm{tu}$ 賛辞 ù-na-a-du $\mathrm{u}_{11}(1-7)$

$\mathrm{a}_{2}$ 賛辞 ù-na-dè-dah (8-15)

$\mathrm{a}_{3}$ 賛辞?（16-?）

b 欠損

C 嘆願

14. エテル・ピ・ダム $\rightarrow$ マルトゥ神

敵対者からの迫害を嘆き庇護を願う

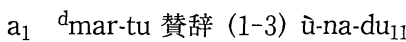
b E-te-el-pi $i_{4}$ - $D a-m u$ arad-zu nu-ub-bé-a (4)
c 嘆願 (5-16)

15. ク・ナンナ $\rightarrow$ ニンシュブル神

ETCSL 3.3.39

社会的疎外を嘆き神の心を有めようとする
$\mathrm{a}_{1} \quad \ldots$ ù-na-a-du 11 (A1-2)
$\mathrm{a}_{2}$ 賛辞 ù-na-dè-dah (A3-12)
b ${ }^{\mathrm{m}} \mathrm{kù}-{ }^{\mathrm{d}}$ nanna ... arad-zu na-bé-a (A13) 
C 嘆願 $(\mathrm{A} 14-\mathrm{B} 13+)$

16. シン・イッディナム $\rightarrow$ ウトゥ神 ETCSL 3.2.05

ラルサを襲った災難を嘆き救出を願う

$\mathrm{a}_{1} \mathrm{~d}_{\text {utu lugal-g̃u }}$ - -úr 賛辞 ù-na-a-du $\mathrm{u}_{11}$ (1-5)

$\mathrm{a}_{2}$ 賛辞 ù-na-dè-dah $(6-10)$

b mdEN. ZU-i-din-nam ... arad-zu na-ab-bé-a (11)

c 嘆願 $(12-46)$

17. シン・イッディナム $\rightarrow$ ニンイシナ神

病魔からの解放を願う

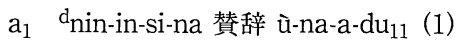

$\mathrm{a}_{2}$ 賛辞 ù-na-dè-dah $(2-10)$

b mdEN. ZU-i-din-nam ... arad-zu na-ab-bé-a (11)

c 嘆願 $(12-52)$

注

(1) A. Falkenstein, "Ein sumerischer 'Gottesbrief'," ZA 44 (1938), 1-25.

(2) B. Böck, “'Wenn du zu Nintinuga gesprochen hast, ...' Untersuchungen zu Aufbau, Inhalt, Sitz-im-Leben und Funktion sumerischer Gottesbriefe," Altorientalische Forschungen 23 (1996), 4, n. 6.

( 3 ) W.W. Hallo, "Individual Prayer in Sumerian: The continuity of a Tradition," JAOS 88 (1968), 71-89; idem., "Two Letter-Prayers to Amurru," M. Lubetski, C. Gottlieb and Sh. Keller (eds.), Boundaries of the Ancient Near Eastern World: A Tribute to Cyrus H. Gordon, JSOT Supp 273, Sheffield, 1998, 397-410.

（4）ウル第三王朝期の手紙命令文書の多くは，P. Michalowski， Letters from Early Mesopotamia [=SBL Writings from the Ancient World 3], Atlanta, 1993 に所収。この 論考のなかでミカロウスキはこれらの文書を archival letters と呼んでいる。

（5）いわゆる「王室書簡royal letters」については, Michalowski, The Royal Correspondence of Ur, PhD Diss. Yale University, 1976; idem., "Königsbriefe," Reallexikon der Assyriologie Band 6, 52 などが参考になる。

（6） アバ・タフ・ルガルガから兄弟たちへの書簡（ETCSL 3.3.06），シャマシュ・ター ブからイラク・ニイドへの書簡 (ETCSL 3.3.08)，ルガル・ネサグからエンリル・マッ スへの書簡 (ETCSL 3.3.09), イニム・イナンナからエンリル・マッスへの書簡 (ETCSL 3.3.11)，イニム・イナンナからルガル・イビラへの書簡 (ETCSL 3.3.12) など。ETCSL とは, 本稿末尾の資料でも示したようにシュメール語の文学テキストを網羅しようとす るオックスフォード大学のデータベースを指す。このデータベースの資料的性格につい ては末尾に注記してある。

（7）ウグビ (猿) からその母への書簡 (ETCSL 3.3.07)。

(8) Michalowski, Letters from Early Mesopotamia, 4. 
( 9$) \quad \mathrm{N}$ 1513; Crozer 206; CBS 2231 (PBS 5 65) i 9'-15'; N 3210+N 3264+N 3266+N $3294+\mathrm{N} 3303+\mathrm{N} 3308+\mathrm{Ni} 9701$ (ISET 2 114) + UM 29-16-139 i 19'-ii 6'; CBS 7848 (PBS 13 46) +CBS $7856+$ CBS 7849 (+) Ni 4574 (ISET 1149$)$ a; U 169000 (UET 8 61) rev. 1'-6'; 3N-T918, 410 (SLFN 21) ii 1-2; 3N-T516 a 2'-8'; 3N-T80 rev. 12'-13'; 将軍シン・イッラトがイッディン・ダガン王に対して, 対峙するマルトゥの状況につい て報告している。

(10) ETCSL 3.1.02:18, 27, 31; 3.1.07:26; 3.1.15:19; 3.2.01:8, 10; 3.2.03:12; 3.3.01:11; 3.3.05:8; 3.3.39:5.

(11) ETCSL 3.1.01:34; 3.1.05:15; 3.1.07:34; 3.1.15:43; 3.1.19:53; 3.2.01:11; 3.3.01:14; 3.3.05:15.

(12) ETCSL 3.1.02:35; 3.1.08:B21; 3.1.10:28; 3.1.16:45; 3.2.02:19; 3.2.03:19; 3.2.04: 17 ; 3.3.04:12; 3.3.06:12; 3.3.07:11;3.3.08:19; 3.3.11:15;3.3.12:12.

（13）「嘆願の書簡」に関して本稿の筆者はかつて本誌第47巻 2 号所収の研究ノートにお いて,「請願の書簡」という表現を用いていたが, 現時点でその言葉遣いは明らかに修正 されるべきである。請願の書簡において, 書き手が, 自らの希望の達成を願い出るのに 対して, 嘆願の書簡では, 書き手がまず自らの苦境を嘆き, その後で苦境からの救出を 願う部分が備わる。

（14）グデアから彼の個人神への書簡（(表 1) 及び末尾資料番号10）。

(15) TCL 3, pl. 1-30. cf. F. Thureau-Dangin, Une Relation de la huitième campagne de Sargon (714 av.J.-C.), Paris, 1912, 2-67.

（16）形式的・内容的にも同類であるにもかかわらず，ベックの分類には，末尾資料の書 簡のうち 1 ～ 7 までは含まれない。ハローもまた， 1 6 までの書簡を議論から除外し ている。

（17）それぞれの書簡に付された 1 〜 17 ぞの番号は末尾資料のテキスト番号と対応し ている。

（18）代表的な例として，ギルガメシュとフワワ（ETCSL 1.8.1.5）17-18; 21-33，イナ ンナの冥界下り（ETCSL 1.4.1）43-47; 52-56; 60-64; 185-189; 199-203; 209-216; 370375がある。

（19）たとえば，グデアの神殿建立碑文（ETCSL 2.1.7）A2.10-19; A2.28-3.28; A4.85.10; A8.15-9.4; B1.21-2.6; B2.16-3.1や，ウトゥヘガル碑文（ETCSL 2.1.6）14-16, 43,47 な゙。

（20）都市滅亡哀歌の末尾には，都市を襲った災厄が再び繰り返されることのないように との願い,さらには都市神が都市を回復するようにとの願いが組み込まれている。代表 的なものとして，ウル滅亡哀歌（ETCSL 2.2.2）402-437，シュメールとウルの滅亡哀 歌（ETCSL 2.2.3）483-518など。前者に関しては, S. N. Kramer, Lamentation Over the Destruction of Ur. Assyriological Studies 12. Chicago, IL: Chicago University Press, 1940 を，後者に関しては, Michalowski, The Lamentation over the Destruction of 
Sumer and Ur. Mesopotamian Civilizations 1. Winona Lake, IN: Eisenbrauns, 1989 を参照せよ。

（21）その他，カッシート朝期までに蓄積された円筒印章の銘文にも，短く簡潔な祈りの 文句がシュメール語によっても刻まれている。個別のテキストに関しては H. Limet, Les légends des sceaux cassites, Bruxelles, 1971 を参照せられたい。

（22）王賛歌は，とくにイシン・ラルサ時代に神格化された王に捧げた作品が数多く残存 する。アダブ (adab) としては, Rim-Sin H (UET6, 100; ETCSL 2.6.9.8) が典型的。 ティギ (tigi) としては, Išbi-Erra C (YBC 9859, HE 527, N 4194; ETCSL 2.5.1.3) などがある。

（23）嘆願の文学書簡でとくに好まれる「祈りを聞く（a-ra-zu g̃iš-tuku）」という表現は， 古バビロニア期の王碑文においても高い頻度で使われていることが確認される。たとえ ば, Sin-iddinam 13:17; Rim-Sin 16:7; Warad-Sin 10:4; Enlil-bani 3:4 など。

(24) エルシャフンガの個々のテキストは, St. M. Maul, 'Herzberuhingsklagen': Die sumerisch-akkadischen Eršahunga-Gebete, Wiesbaden: Otto Harrassowitz, 1988 のなか に集められている。

(25) Michalowski, "On the Early History of the Eršahunga Prayer," JCS 39 (1987), 37-48.

（26）（表 1) 及び末尾（資料）1-6, 7 (?)。

(27) Hallo, "Letters, Prayers and Letter-Prayers," in Proceeding of the Seventh World Congress of Jewish Studies: Studies in the Bible and the Ancient Near East held at The Hebrew University of Jerusalem 7-14 August 1977 under the Auspices of The Israel Academy of Sciences and Humaities. Jerusalem, 1981, 17-27; idem, "Two LetterPrayers to Amurru,” 410. 加えて，口頭によるハローとの会話において。

(28) Hallo, "Two Letter-Prayers to Amurru," 401.

(29) D. Charpin, "Les malheurs d'un scribe," in M. de Jong Ellis (ed.) Nippur at the Centennial (CRRAI 35), Philadelphia, 1992, 22.

（30）高井啓介「アッカド語による『神への請願の手紙』」オリエント』47 (2005), 6479.

(31) F. R. Kraus, "Eine neue Probe akkadischer Literatur: Brief eines Bittstellers an eine Gottheit,” JAOS 103 (1983), 205-209.

（32）具体的には, 書簡の書き手であるシン・ナディム・シュミムがナブ神によって嘆願 が聞き届けられるのにふさわしいことを保証するために, 忠実な奉仕者 (表 $1 \mathrm{~b})$ として 自らを提示するとともに, 悲願が成就した際に行うべき義務（表 1e）をあらかじめ述べ ており，両者で苦境の描写 (表 1c) を挟み込むところはシュメール語の嘆願の文学書簡 の手法と通じるものがある。

（33） アラド・グからシュルギ王への書簡（ETCSL 3.1.06）のコピーCBS 346， ウル・ シャガから王への書簡 (No.6; ETCSL 3.3.01) のコピーW16743b, 差出人不明のナン 
ナ神への書簡（No.12; ETCSL 3.3.22）のコピーW17259w，シュルギ王からイシュビ・ エッラ宛の書簡（ETCSL 3.1.13.2）のコピーSusa A XII/1 1962/3 の計四点である。

(34) Charpin, “Les malheurs d'un scribe," 7-27 に所収。

（35）この点に関しては，本稿の筆者が，高井啓介「なぜかれらは二言語併記で書かなけ ればならなかったのか？～古バビロニア期のバイリンガル書簡についての考察〜」飯田 隆編『西洋精神史における言語と言語観＼cjkstart継承と創造』慶應義塾大学出版会，2005，5874 で検討を加えている。

(36) OBTR 150; S. Dalley, C. B. F. Walker, and J. D. Hawkins, The Old Babylonian Tablets from Tell Al Rimah, British School of Archaeology in Iraq, 1976, 122-123. $ア$ ッカド語文学テキストの翻訳の最新の改訂版である B. Foster, Before the Muses. An Anthology of Akkadian Literature, CDL Press, Bethesda, 2004 においては, ジムリ・リ ム書簡とイルタニ書簡の二点が「書記の請願とエクササイズ」という項目の下に新たに 分類された。

(37) ME 94; D. Arnaud, Textes Syriens de l'âge du bronze récent. AuOr Sup 1, Sabadell (Barcelona), 1991, 153, no. 101; M. Civil, N.A.B.U. 53 (1996), 36-37.

(38) K4615 (published as OECT 6, pl. XVIII) ; K4847; K4958 (OECT 6, pl. XX) +K $5947+\mathrm{K} 8208+\mathrm{K} 6598+\mathrm{K} 7571+\mathrm{K} 11068+\mathrm{K} 13524+\mathrm{K} 13763+\mathrm{K} 17479+\mathrm{K} 20098$; R. Borger, "Ein Brief Sin-iddinams von Larsa an den Sonnengot sowie Bemerkungen der 'Joins' und das 'joinen'”, Nachrichten der Akademie der Wissenschaften in Göttingen, I. Phil. -Hist. Kl. Nr. 2, Göttingen (1991), 1-45. 